JKT, 2018;9(1):32-44. Pengaruh Pelatihan terhadap Pengetahuan, Sikap, dan Praktik

Jacomina Anthonete Salakory

\title{
PENGARUH PELATIHAN TERHADAP PENGETAHUAN, SIKAP, DAN PRAKTIK KADER TENTANG PENYULUHAN PENCEGAHAN HIV/AIDS DI PUSKESMAS HATIVE KECIL
}

The Effect of Training on Cadre Knowledge, Attitude and Practice Towards Education of HIV/AIDS Prevention at Public Health Service of Hative Kecil in Ambon

\author{
Jacomina Anthonete Salakory ${ }^{1}$ \\ ${ }^{1}$ Jurusan Kebidanan Poltekkes Kemenkes Maluku, Jalan Laksdya Leo Wattimena, Negeri Lama, \\ Ambon \\ Email: ann.salakory@gmail.com
}

\begin{abstract}
HIV/AIDS cases in Ambon has shown a vast growth down the years. Cadres of integrated public health service (Posyandu) as the spearhead of the basic health services in their local community are potentials to be improved to socialize the prevention of the HIV/AIDS. This research aimed to find out effect of training on cadre knowledge towards education of HIV/AIDS prevention at Public Health Service of Hative Kecil in Ambon. The research used a quantitative method and quasi-experimental technique with pre test-post test non-equivalent control group method. There were 30 respondents attending the training programme delivered by class room tutorials, discussions, interviews, and holistic practices, either in indoor or outdoor settings using leaflets and modules. Indeed, all the respondents only received the leaflets. The determination of the samples was according to a purposive sampling method. Statistical test on cadre knowledge resulted in $\mathrm{p}_{\text {value }}=0.348$; post test $1 \mathrm{p}$-value $=$ 0.000 and post test $2 \mathrm{p}$ - value $=0.000$. On cadre attitude resulted in $\mathrm{p}_{\text {value }}=0.057$ and post test $1 \mathrm{p}_{\text {-value }}=$ 0.450 ; and post test $2 \mathrm{p}$-value $=0.000$. The average practice score of pre test and post test 1 was 0 , $\mathrm{p}$-value $=1.00$. The average practice score of post test 2 of the intervention group was 15.93 and control group was 11.20, $\mathrm{p}_{\text {value }}=0.000$. Training can improve knowledge, attitude, and practice of the cadres. Knowledge which is applied on daily activities may turn into a particular lifestyle and may be sustainable. The trained Posyandu cadres can improve their knowledge by a periodical updating by the local office of health affairs.
\end{abstract}

Keywords: Training, knowledge, attitude, practice, HIV/AIDS, cadre

\section{ABSTRAK}

Kasus HIV/AIDS pada ibu rumah tangga di Ambon dari tahun ke tahun semakin meningkat, yang memberi peluang meningkatnya jumlah anak dengan HIV. Kader posyandu sebagai ujung tombak pelayanan kesehatan dasar di masyarakat dapat diberdayakan untuk mensosilisasikan pencegahan HIV/AIDS. Upaya pencegahan ini diintegrasikan kedalam tugas kader posyandu untuk memberikan penyuluhan pencegahan HIV/AIDS. Jenis penelitian kuantitatif, kuasi eksperimen dengan rancangan pre test post ttest non-equivalent control group. 30 responden mendapatkan pelatihan dan 30 responden mendapatkan leaflet. cara pengambilan sampel purposive sample. Hasil uji statistik terhadap pengetahuan kader, $p$-value $=0,348$ (tidak ada perbedaan pengetahuan antara kedua kelompok sebelum intervensi). Post test 1 -value $=0,000$ dan Post test 2, $p$-value $=0,000$ (ada perbedaan pengetahuan antara kedua kelompok). Hasil uji statistik terhadap sikap, kader, $p$-value $=0,057$ dan Post test $1 p$ value $=0,450$ (tidak ada perbedaan sikap antara kedua kelompok). Post test 2, p-value $=0,000$ (ada perbedaan sikap antara kedua kelompok). Rata-rata skor praktik pre test dan post test 1 adalah $0, p$ value $=1,00$ (tidak ada perbedaan praktik antara kedua kelompok). Post test 2 kelompok intervensi 15,93 dan kelompok kontrol 11,20, p-value = 0,000 (ada perbedaan praktik antara kedua kelompok). Pelatihan disertai dengan praktik menyuluh dapat meningkatkan pengetahuan, sikap dan praktik kader. Disarankan kepada DKK Ambon, agar Kader posyandu yang telah dilatih, dapat ditingkatkan lagi pengetahuannnya dengan dilakukan penyegaran kader secara periodik.

Kata kunci: Pelatihan, pengetahuan, sikap dan praktik, HIV/AIDS, kader 
JKT, 2018;9(1):32-44. Pengaruh Pelatihan terhadap Pengetahuan, Sikap, dan Praktik...

Jacomina Anthonete Salakory

\section{PENDAHULUAN}

Human Immunodeficiency Virus (HIV) merupakan virus yang menyerang sistem kekebalan tubuh yang fungsinya melindungi tubuh dari serangan penyakit. Infeksi HIV adalah infeksi kronis, dalam waktu yang panjang akan berkembang menjadi Acquired Immunodeficiency Syndrome (AIDS) dan berakhir dengan kefatalan. Sejak seseorang terinfeksi HIV, ia berpotensi menularkan HIV kepada orang lain. Perjalanan HIV menjadi AIDS memerlukan waktu bertahun-tahun, seseorang yang terinfeksi HIV tampak sehat, tanpa gejala, namun berpotensi menularkan kepada orang lain. AIDS merupakan kumpulan gejala yang disebabkan oleh HIV. Virus HIV ditemukan dalam cairan tubuh terutama dalam darah, cairan sperma, cairan vagina dan Air Susu Ibu (ASI) ${ }^{1}$.

Angka kejadian HIV/AIDS di provinsi Maluku, sejak tahun 1994 - 2010 yaitu 1.763 kasus (HIV 1.275 kasus dan AIDS 488 kasus). Persentase kasus HIV/AIDS menurut faktor risiko: heteroseksual 59\% dan perinatal 4\% ${ }^{1}$. Jumlah kasus HIV/AIDS di kota Ambon sejak tahun 1994 - 2012 adalah 935 kasus. Pada tahun 2013 - Mei 2014 penambahan kasus baru berjumlah 146 kasus, dengan rincian HIV 81 kasus dan AIDS 65. Jumlah kasus HIV/AIDS menurut faktor risiko: heteroseksual 548 kasus $(58,6 \%)$ dan perinatal 76 kasus $(8,1 \%)$. Jumlah kumulatif kasus HIV/AIDS menurut jenis kelamin: laki-laki 612 kasus, perempuan 469 kasus. Jumlah kumulatif kasus AIDS yang hidup 494 kasus dan meninggal 592 kasus ${ }^{1}$.

Melihat jumlah kasus diatas, dimana terjadi peningkatan kasus HIV/AIDS setiap tahun, maka diperkirakan pada tahun 2015, angka HIV/AIDS di Indonesia akan mencapai 1.000.000 kasus dengan kematian 350.000 orang, karena perkembangan kasus ini telah sampai ke masyarakat umum. Diperkirakan pada tahun 2015, total kumulatif 38.500 anak akan menjadi positif HIV disebabkan transimi HIV ibu - anak ${ }^{1}$.

Penularan HIV dari ibu kepada bayinya bisa terjadi selama masa kehamilan, masa persalinan, dan masa menyusui. Penularan HIV dari ibu ke bayi merupakan akhir dari rantai penularan yang kemungkinan berawal dari seorang laki-laki HIV positif yang menularkan HIV kepada pasangan perempuannya melalui hubungan seksual tak aman, dan selanjutnya pasangan perempuan menularkan HIV kepada bayi yang dikandungnya. Sepanjang usia reproduksi aktifnya, secara potensial perempuan masih memiliki risiko untuk menularkan HIV kepada bayi berikutnya jika ia kembali hamil ${ }^{2}$.

Untuk mengurangi penularan HIV dan AIDS, maka Dinas Kesehatan Kota Ambon telah melakukan berbagai kegiatan. Kegiatan terkait pencegahan penularan HIV/AIDS yang telah dilakukan Dinas Kesehatan Kota Ambon selama ini lebih berfokus pada kegiatan survei IMS, HIV, pendampingan ODHA (Orang dengan HIV/AIDS), pengobatan infeksi oportunistik, pelatihan peer educator pada kelompok ODHA, distribusi kondom, VCT, CST. Kegiatan sosialisasi oleh puskesmas Hative Kecil kepada masyarakat belum berjalan dengan maksimal karena keterbatasan dana.

Agar maksimal upaya pencegahan penularan HIV/AIDS di dalam masyarakat, maka perlu diselenggarakan berdasarkan prinsip kemitraan antara pemerintah, masyarakat, organisasi yang peduli AIDS maupun kelompok agama. Pencegahan penularan yang melibatkan masyarakat lebih berupa pencegahan yang bersifat primer, yang bertujuan mencegah penularan HIV dari ibu ke anak secara dini, yaitu baik sebelum terjadinya perilaku berhubungan seksual berisiko atau bila terjadi perilaku seksual berisiko, maka penularan masih bisa dicegah, termasuk mencegah wanita dan ibu hamil agar tidak tertular oleh pasangannya yang terinfeksi HIV. Upaya pencegahan ini tentunya harus dilakukan dengan penyuluhan dan penjelasan yang benar terkait penyakit HIV/AIDS.

Posyandu merupakan wadah titik temu antara pelayanan profesional dari petugas kesehatan dan peran serta masyarakat dalam menanggulangi masalah kesehatan masyarakat, terutama dalam upaya penurunan Angka Kematian Bayi (AKB) dan angka kelahiran.

Kader kesehatan merupakan perwujudan peran serta aktif masyarakat dalam pelayanan terpadu. Kader mampu melaksanakan tugasnya dengan baik, jika kader dibekali dengan pengetahuan yang baik dan dilengkapi dengan kecakapan dalam melakukan tindakan terkait 
pelayanannya, melalui pelatihan kader. Peran kader dalam penyelengaraan posyandu sangat besar karena selain sebagai pemberi informasi kesehatan juga sebagai penggerak masyarakat untuk datang posyandu. Kirkpatrick mendefinisikan pelatihan sebagai upaya meningkatkan pengetahuan, mengubah perilaku dan mengembangkan keterampilan peserta ${ }^{3}$. Penggunaan metode ceramah, tugas baca, panel dan konseling dapat mengubah pengetahuan peserta latih $^{1,4}$.

Saat pelaksanaan posyandu, penyuluhan yang diberikan oleh kader posyandu lebih berupa nasihat meliputi makanan bergizi dan upaya untuk meningkatkan berat badan bayi/anak. Saat memberikan penyuluhan kepada ibu/masyarakat, kader tidak menggunakan media penyuluhan. Penyampaian informasi tentang PPIA belum pernah disampaikan kepada masyarakat, karena kader belum pernah mendapatkan informasi secara lengkap tentang pencegahan penularan HIV/AIDS dari ibu ke anak.

Hasil penelitian yang dilakukan Jumiati didapatkan bahwa pelatihan dengan menggunakan modul dapat meningkatkan pengetahuan, sikap, dan praktik kader dalam upaya pemberian ASI eksklusif dibandingkan kelompok kontrol. Dimana terjadi peningkatan skor pengetahuan dari post-test bulan pertama 8,94 poin dan post-test bulan kedua 1,55 poin. Sikap meningkat sebesar 6,35 poin post-test bulan pertama dan pada post-test bulan kedua tidak terjadi peningkatan, praktik meningkat sebesar 4,55 poin, post-test bulan pertama 11,8 poin dan post-test bulan kedua 0,39 poin $^{5}$.

Begitu juga hasil penelitian Sukiarko menunjukan bahwa metode belajar berdasakan masalah meningkatkan rerata skor pengetahuan saat pos-test 19,19 poin dan keterampilan 11,75 poin. Pada post-test 2 terjadi peningkatan skor pengetahuan 8,61 poin dan keterampilan 16,35 poin $^{4}$. Tujuan dari penelitian ini adalah untuk mengetahui pengaruh pelatihan terhadap pengetahuan, sikap dan praktik kader dalam penyuluhan pencegahan penularan HIV/AIDS di Puskesmas Hative Kecil.

\section{METODE}

Jenis penelitian ini adalah kuantitatif, kuasi eksperimen dengan rancangan pre test post test non-equivalent control group. Jumlah responden 60 yang terdiri dari 30 responden diberikan perlakuan pelatihan dan 30 responden mendapatkan leaflet. Cara pengambilan sampel purposive sample. Yang hendak dilihat dari pelatihan ini adalah pengetahuan kader tentang pencegahan penularan HIV/AIDS dari ibu ke anak (PPIA). Peningkatan pengetahuan kader didapatkan dari hasil pre test (sebelum dilakukan perlakuan), post test 1 (sehari setelah diberikan perlakuan pelatihan) dan post test 2 (sebulan setelah pelatihan). Dalam penelitian ini salah satu kelompok diberi perlakuan pelatihan (dengan menggunakan media modul dengan metode ceramah, diskusi-tanya jawab, demonstrasi serta praktik penyuluhan di dalam dan di luar ruangan serta sebagai media penyuluhan diberikan leaflet). Kelompok yang kedua diberi leaflet tentang pencegahan penularan HIV/AIDS dari ibu ke anak sebagai media belajar.

Penelitian ini dilakukan pada kader posyandu di wilayah kerja puskesmas Hative Kecil dan puskesmas Tawiri berupa kegiatan pelatihan yang dilakukan selama dua hari. Populasi dalam penelitian ini adalah semua kader yang berada dilingkungan kerja Puskesmas Hative Kecil dan Tawiri. Sampel penelitian berjumlah 30 orang dengan kriteria kader aktif berusia antara 20 - 49 tahun, dengan masa kerja 2 - 10 tahun, dapat berbahasa Indonesia aktif, pendidikan sekurang-kurangnya SMP, berdomisili pada desa Galala dan Hative Kecil, berbadan sehat jasmani dan rohani.

Kelompok kontrol adalah kader posyandu pada Puskesmas Tawiri yang diberi leaflet, berjumlah 30 orang, memiliki kriteria sama dengan kelompok intervensi pelatihan. Jarak antara kedua lokasi penelitian adalah kurang lebih $20 \mathrm{~km}$.

Variabel dalam penelitian ini terdiri dari variabel independen yaitu pelatihan, variabel dependennya adalah pengetahuan, sikap dan praktik kader. 
JKT, 2018;9(1):32-44. Pengaruh Pelatihan terhadap Pengetahuan, Sikap, dan Praktik

Jacomina Anthonete Salakory

Hasil penelitian dianalisis secara univariat, bivariat. Analisis statistik yang di gunakan adalah Wilcoxon untuk membandingkan hasil rerata pre test, post test 1 dan post test 2 baik pada kelompok intervensi maupun pada kelompok kontrol. Guna membedakan rerata pre test, post test 1 dan post test 2 pengetahuan, sikap dan praktik antara kedua kelompok baik melalui pelatihan maupun leaflet digunakan uji Mann Whitney yang merupakan uji alternatif dari $t$-test, karena data terdistribusi tidak normal.

\section{HASIL}

\section{A. Karakteristik responden}

Karekteristik responden pada kedua kelompok adalah sebagai berikut:

Tabel 1. Distribusi frekuensi responden berdasarkan karakteristik (umur, pendidikan, pekerjaan dan lama jadi kader) pada kelompok intervensi dan kontrol $\left(\mathbf{n}_{1}=30\right.$ dan $\left.\mathbf{n}_{2}=30\right)$

\begin{tabular}{|c|c|c|c|c|c|c|}
\hline \multirow{2}{*}{$\begin{array}{c}\text { Karakteristik } \\
\text { Responden }\end{array}$} & \multicolumn{2}{|c|}{$\begin{array}{l}\text { Kelompok } \\
\text { Intervensi }\end{array}$} & \multirow[t]{2}{*}{$\mathrm{N}$} & \multicolumn{2}{|c|}{ Kelompok Kontrol } & \multirow[t]{2}{*}{$p$-value } \\
\hline & $\mathrm{n}$ & $\%$ & & $\mathrm{n}$ & $\%$ & \\
\hline \multicolumn{7}{|l|}{ Umur } \\
\hline 22-37 tahun & 16 & 53,3 & \multirow{2}{*}{30} & 13 & 43,3 & \multirow{2}{*}{0,783} \\
\hline 38-48 tahun & 14 & 46,7 & & 17 & 56,7 & \\
\hline \multicolumn{7}{|l|}{ Pendidikan } \\
\hline SMP & 5 & 16,7 & \multirow[t]{2}{*}{30} & 3 & 10,0 & \multirow[t]{2}{*}{0,138} \\
\hline SMA & 25 & 83,3 & & 27 & 90,0 & \\
\hline \multicolumn{7}{|l|}{ Pekerjaan } \\
\hline Bekerja & 2 & 6,7 & \multirow[t]{2}{*}{30} & 1 & 3,3 & \multirow[t]{2}{*}{0,057} \\
\hline Tidak Bekerja & 28 & 93,3 & & 29 & 96,7 & \\
\hline \multicolumn{7}{|l|}{ Lama jadi Kader } \\
\hline $2-5$ tahun & 15 & 50,0 & 30 & 20 & 66,7 & 0,934 \\
\hline $6-10$ tahun & 15 & 50,0 & & 10 & 33,3 & \\
\hline
\end{tabular}

1. Umur responden

Tabel 2. Hasil uji beda rata-rata umur responden dengan $t$-test

\begin{tabular}{llccc}
\hline No. & Umur Responden & Mean & Minimal & Maksimal \\
\hline 1. & Kelompok intervensi & 37,6 & 22 & 48 \\
2. & Kelompok kontrol & 38,1 & 28 & 48 \\
& & p-value $=0,783$ & & \\
\hline
\end{tabular}

Tabel 1 menunjukkan bahwa umur dewasa pertengahan pada kelompok intervensi lebih besar $(53,3 \%)$ daripada kelompok kontrol $(46,7 \%)$. Tabel 2 menunjukkan bahwa rata-rata umur, umur termuda dan tertua antara kelompok intervensi dan kontrol berbeda, meskipun perbedaan itu sangat kecil. Untuk membuktikan bahwa umur responden pada kelompok kontrol tidak ada perbedaan dilakukan dengan independent sampel t-test karena umur responden adalah data numerik dengan skala rasio serta data terdistribusi normal. Pada uji Levenes dihasilkan p-value sebesar 0,453 yang berarti varians kedua kelompok sama. Output yang dipilih untuk dijadikan pengambilan keputusan adalah equal varians assumed dengan $p$-value sebesar 0,783 . Ini berarti tidak ada perbedaan umur yang signifikan antara kelompok intervensi dengan kelompok kontrol. 


\section{Pendidikan}

Secara umum, pendidikan responden pada kedua kelompok adalah sama yaitu pendidikan menengah. Dengan uji Mann Whitney terbukti bahwa p-value 0,138 menunjukkan tidak ada perbedaan pendidikan antara kelompok intervensi dan kontrol. Secara rinci, dapat dilihat pada tabel 3.

Tabel 3. Rincian pendidikan responden menurut jenjang pendidikan pada kelompok intervensi dan kelompok kontrol

\begin{tabular}{crcccc}
\hline \multirow{2}{*}{ No. } & \multirow{2}{*}{ Pendidikan } & \multicolumn{2}{c}{ Kelompok intervensi } & \multicolumn{2}{c}{ Kelompok Kontrol } \\
\cline { 3 - 6 } & & $\mathrm{n}$ & $\%$ & $\mathrm{n}$ & $\%$ \\
\hline 1. & SD & 0 & 0,0 & 0 & 0,0 \\
2. & SMP & 5 & 16,7 & 3 & 10,0 \\
3. & SMA & 25 & 83,3 & 27 & 90,0 \\
4. & D3/S1/S2/S3 & 0 & 0,0 & 0 & 0,0 \\
& Jumlah & 30 & 100,0 & 30 & 100,0 \\
\hline
\end{tabular}

Secara umum, jenjang pendidikan yang telah ditempuh adalah SMA baik kelompok intervensi $(83,3 \%)$ dan kelompok kontrol yaitu 90,0\%. Tidak ada responden pada kedua kelompok tersebut yang pendidikannya SD dan D3/S1/S2/S3.

\section{Pekerjaan}

Secara umum, responden dalam penelitian ini, baik kelompok intervensi maupun kelompok kontrol tidak bekerja. Uji Mann Whitney menghasilkan p-value sebesar 0,557 yang berarti tidak ada beda jenis pekerjaan antara kelompok intervensi dengan kelompok kontrol.

Tabel 4. Rincian jenis pekerjaan responden menurut jenis pekerjaan pada kelompok intervensi dan kelompok kontrol

\begin{tabular}{clcccc}
\hline \multirow{2}{*}{ No. } & Jenis pekerjaan & \multicolumn{2}{c}{ Kelompok intervensi } & \multicolumn{2}{c}{ Kelompok Kontrol } \\
\cline { 3 - 6 } & \multicolumn{1}{c}{ responden } & $\mathrm{n}$ & $\%$ & $\mathrm{n}$ & $\%$ \\
\hline 1. & PNS & 0 & 0,0 & 0 & 0,0 \\
2. & Swasta & 0 & 0,0 & 0 & 0,0 \\
3. & Wiraswasta & 2 & 6,7 & 1 & 3,3 \\
4. & Tidak Bekerja & 28 & 93,3 & 29 & 96,7 \\
& Jumlah & 30 & 100,0 & 30 & 100,0 \\
\hline
\end{tabular}

4. Lama menjadi kader

Tabel 5. Hasil uji beda lama responden menjadi kader dengan uji Mann Whitney

\begin{tabular}{clccc}
\hline No. & Lama menjadi kader & Mean (tahun) \pm Median & $\begin{array}{c}\text { Minimal } \\
\text { (tahun) }\end{array}$ & $\begin{array}{c}\text { Maksimal } \\
\text { (tahun) }\end{array}$ \\
\hline 1. & Kelompok perlakuan & $5,47 \pm 5,5$ & 2 & 10 \\
2. & Kelompok kontrol & $\begin{array}{c}5,47 \pm 5,5 \\
\text { p-value }=0,934\end{array}$ & 2 & 10 \\
\hline
\end{tabular}

Tabel 5. menunjukkan bahwa pada kelompok intervensi, responden dengan lama kader kurang dari lima tahun lebih sedikit yaitu 50,0\% daripada kelompok kontrol (66,7\%). Dengan uji Mann Whitney (karena data terdistribusi tidak normal) yang menghasilkan p-value 0,934 yang mendekati 1, artinya tidak ada perbedaan lama responden menjadi kader antara kelompok intervensi dengan kelompok kontrol. 
JKT, 2018;9(1):32-44. Pengaruh Pelatihan terhadap Pengetahuan, Sikap, dan Praktik.

Jacomina Anthonete Salakory

B. Gambaran pengetahuan, sikap, dan praktik responden dalam penyuluhan pencegahan HIV/AIDS sebelum dan sesudah intervensi

1. Pengetahuan, sikap dan praktik kader sebelum intervensi pada kedua kelompok

Tabel 6. Distribusi perbedaan pengetahuan, sikap dan praktik responden sebelum diberi intervensi pada kedua kelompok $\left(\mathbf{n}_{1}=30\right.$ dan $\left.\mathbf{n}_{2}=30\right)$

\begin{tabular}{|c|c|c|c|c|c|c|c|}
\hline \multirow{3}{*}{$\begin{array}{l}\text { Perilaku } \\
\text { Kader }\end{array}$} & \multicolumn{6}{|c|}{ Kelompok } & \multirow{3}{*}{$p$-value } \\
\hline & \multicolumn{3}{|c|}{$\begin{array}{l}\text { Intervensi } \\
\text { Sebelum }\end{array}$} & \multicolumn{3}{|c|}{$\begin{array}{l}\text { Kontrol } \\
\text { Sebelum }\end{array}$} & \\
\hline & Min & Max & Mean \pm Median & Min & Max & Mean \pm Median & \\
\hline Pengetahuan & 8 & 20 & $13,63 \pm 14,00$ & 7 & 20 & $14,53 \pm 15,00$ & 0,348 \\
\hline Sikap & 5 & 22 & $18,06 \pm 19.00$ & 14 & 20 & $19,50 \pm 20.00$ & 0,057 \\
\hline Praktik & 0 & 0 & 0 & 0 & 0 & 0 & 1,000 \\
\hline
\end{tabular}

Tabel 6. menujukkan bahwa skor minimal pengetahuan pada kelompok intervensi 8 dan kelompok kontrol 7, tertinggi pada kedua kelompok sama yaitu 20.

Skor minimal sikap pada kelompok intervensi 5 dan kelompok kontrol 14, skor maksimal pada kelompok intervensi 22, dan kelompok kontrol 20.

Skor praktik pada kedua kelompok adalah sama 0 .

2. Pengetahuan, sikap dan praktik kader satu hari setelah intervensi pada kedua kelompok

Tabel 7. Distribusi perbedaan pengetahuan, sikap dan praktik kader sehari setelah diberi intervensi pada kedua kelompok $\left(\mathbf{n}_{1}=30, \mathbf{n}_{2}=30\right)$

\begin{tabular}{|c|c|c|c|c|c|c|c|}
\hline \multirow{3}{*}{$\begin{array}{c}\text { Perilaku } \\
\text { Kader }\end{array}$} & \multicolumn{6}{|c|}{ Kelompok } & \multirow{3}{*}{ p-value } \\
\hline & \multicolumn{3}{|c|}{$\begin{array}{c}\text { Intervensi } \\
\text { Sebelum }\end{array}$} & \multicolumn{3}{|c|}{$\begin{array}{l}\text { Kontrol } \\
\text { Sebelum }\end{array}$} & \\
\hline & Min & Max & Mean \pm Median & Min & $\operatorname{Max}$ & Mean \pm Median & \\
\hline Pengetahuan & 12 & 20 & $17,07 \pm 17,00$ & 9 & 20 & $15,40 \pm 15,00$ & 0,003 \\
\hline Sikap & 19 & 22 & $21,43 \pm 22,00$ & 17 & 22 & $20,80 \pm 22,00$ & 0,450 \\
\hline Praktik & 0 & 0 & 0 & 0 & 0 & 0 & 1,000 \\
\hline
\end{tabular}

Tabel 7. menujukkan bahwa skor pengetahuan terendah pada kelompok intervensi 12 kelompok kontrol 9. Skor tertinggi pada kedua kelompok sama yaitu 20.

Skor sikap tertinggi pada kedua kelompok intervensi adalah sama dengan nilai median 22,00 .

Skor praktik pada kedua kelompok sama yaitu 0 .

3. Pengetahuan, sikap dan praktik kader pada kedua kelompok satu bulan setelah intervensi.

Tabel 8. Distribusi perbedaan pengetahuan, sikap dan praktik kader satu bulan setelah diberi intervensi pada kedua kelompok $\left(\mathbf{n}_{1}=30, \mathbf{n}_{2}=30\right)$

\begin{tabular}{|c|c|c|c|c|c|c|c|}
\hline \multirow{3}{*}{$\begin{array}{l}\text { Perilaku } \\
\text { Kader }\end{array}$} & \multicolumn{6}{|c|}{ Kelompok } & \multirow{3}{*}{$p$-value } \\
\hline & \multicolumn{3}{|c|}{$\begin{array}{l}\text { Intervensi } \\
\text { Post test } 2\end{array}$} & \multicolumn{3}{|c|}{$\begin{array}{c}\text { Kontrol } \\
\text { Post test } 2\end{array}$} & \\
\hline & Min & Max & Mean \pm Median & Min & Max & Mean \pm Median & \\
\hline Pengetahuc & 18 & 20 & $18,30 \pm 18,00$ & 11 & 20 & $16,23 \pm$ & 0,000 \\
\hline Sikap & 21 & 22 & $21,97 \pm 22,00$ & 17 & 22 & $20,20 \pm$ & 0,000 \\
\hline Praktik & 14 & 17 & $15,93 \pm 16,00$ & 13 & 16 & $11,20 \pm 11,00$ & 0,000 \\
\hline
\end{tabular}


JKT, 2018;9(1):32-44. Pengaruh Pelatihan terhadap Pengetahuan, Sikap, dan Praktik

Jacomina Anthonete Salakory

Tabel 8. menujukkan bahwa skor pengetahuan kelompok intervensi 18, dan kelompok kontrol 11, skor tertinggi kedua kelompok sama yaitu 20.

Tabel di atas menujukkan bahwa skor sikap pada kelompok intervensi lebih tinggi yaitu 21, pada kelompok kontrol 17. Skor tertinggi kedua kelompok sama, yaitu 22.

Tabel 8. menujukkan bahwa skor praktik pada kelompok intervensi 17 dan kelompok kontrol 16.

C. Analisis perbedaan pengetahuan, sikap dan praktik responden kelompok intervensi dan kontrol sebelum dan setelah pelaksanaan intervensi

Tabel 9. Distribusi perbedaan pengetahuan, sikap dan praktik responden sebelum dan setelah pelaksanaan intervensi antara kelompok intervensi dan kelompok kontrol

\begin{tabular}{llccc}
\hline $\begin{array}{c}\text { Perilaku } \\
\text { Responden }\end{array}$ & $\begin{array}{c}\text { Kelompok } \\
\text { Intervensi } \\
\text { Mean } \pm \text { Median }\end{array}$ & $\mathrm{n}$ & $\begin{array}{c}\text { Kelompok } \\
\text { Kontrol } \\
\text { Mean } \pm \text { Median }\end{array}$ & p-value \\
\hline $\begin{array}{l}\text { Pengetahuan } \\
\text { Pre test }\end{array}$ & $13,63 \pm 14,00$ & 30 & & \\
Post Test 1 & $17,07 \pm 17,00$ & & $14,53 \pm 15,00$ & 0,348 \\
Post test 2 & $18,30 \pm 18,00$ & & $16,40 \pm 15,00$ & 0,000 \\
Sikap & & 30 & & 0,000 \\
Pre test & $18,06 \pm 19,00$ & & $19,50 \pm 20,00$ & 0,057 \\
Post Test 1 & $21,43 \pm 22,00$ & & $20,80 \pm 22,00$ & 0,450 \\
Post test 2 & $21,97 \pm 22,00$ & 30 & $20,20 \pm 21,00$ & 0,000 \\
Praktik & & 30 & $0,00 \pm 0,00$ & 1,00 \\
Pre test & $0,00 \pm 0,00$ & & $0,00 \pm 0,00$ & 1,00 \\
Post Test 1 & $0,00 \pm 0,00$ & & $11,20 \pm 11,00$ & 0,000 \\
Post test 2 & $15,93 \pm 16,00$ & & & \\
\hline
\end{tabular}

1. Perbedaan pengetahuan responden tentang pencegahan penularan HIV/AIDS

Hasil analisis nilai median skor pengetahuan kelompok intervensi adalah 14,00 dan 15,00 untuk kelompok kontrol. Hasil uji statistik dengan menggunakan uji beda Mann Whitney didapatkan $p$-value sebesar $0,348>\alpha=0,05$. Berarti pada alpha $5 \%$ tidak terdapat perbedaan yang bermakna antara pengetahuan kelompok intervensi dengan kelompok kontrol pada saat pre test.

Hasil analisis nilai median skor pengetahuan pada kelompok intervensi setelah dilakukan pelatihan (post test 1) adalah 17,00 dan untuk kelompok kontrol skor pengetahuan adalah 15,00. Hasil uji statistik didapatkan $p$-value sebesar $0,000<\alpha$ $=0,05$, berarti pada alpha $5 \%$ terdapat perbedaan yang bermakna antara pengetahuan kelompok intervensi dengan kelompok kontrol sehari setelah pelatihan (post test 1 ).

Hasil analisis nilai median skor pengetahuan pada kelompok intervensi setelah dilakukan pelatihan (post test 2) adalah 18,00 dan untuk kelompok kontrol 17,00. Hasil uji statistik didapatkan $p$-value sebesar $0,0001<\alpha=0,05$ yang artinya ada perbedaan yang sangat signifikan antara pengetahuan kelompok intervensi dengan kelompok kontrol pada post test 2.

Hasil analisis menunjukkan terjadi peningkatan nilai median pengetahuan sebelum intervensi pelatihan 14,00 menjadi 18,00 sesudah pelatihan pada kelompok intervensi terjadi peningkatan nilai median pengetahuan antara sebelum dan sesudah pelatihan adalah 4,00. Hasil uji statistik menunjukkan $p$-value sebesar $0,0001<\alpha$ $=0,05$ yang berarti ada perbedaan yang sangat signifikan antara pengetahuan responden sebelum pelatihan dengan pengetahuan responden sebulan setelah pelatihan. 
Hasil analisis menunjukkan nilai median pengetahuan kelompok kontrol sebelum dan setelah dibagikan leaflet adalah adalah sama 15.00, 1 bulan setelah pembagian leaflet meningkat menjadi 17,00 . Terjadi peningkatan nilai median pengetahuan antara sebelum dan sesudah pelatihan adalah 2,00. Hasil uji statistik menunjukkan $p$-value sebesar $0,042<\alpha=0,05$ yang berarti ada perbedaan sangat signifikan antara pengetahuan responden sebelum dan sesudah intervensi.

2. Perbedaan sikap repsonden pada kelompok intervensi dan kelompok kontrol

Perbandingan rerata skor sikap antara kelompok intervensi dan kelompok kontrol dilakukan untuk mengetahui perbedaan rerata skor sikap kader sebelum dilaksanakan pelatihan dan sesudah pelatihan (pre test, post test 1, post test 2). Nilai median skor sikap kelompok intervensi adalah 19.00 dan kelompok kontrol rata-rata skor sikap adalah 20.00. Hasil uji statistik dengan menggunakan uji beda Mann Whitney didapatkan $p$-value sebesar $0,057>\alpha=0,05$ yang artinya tidak ada perbedaan yang signifikan antara sikap kelompok intervensi dengan kelompok kontrol pada saat pre test.

Hasil analisis nilai median skor sikap pada kelompok intervensi setelah dilakukan pelatihan (post test 1) adalah 22.00 sedangkan untuk kelompok kontrol nilai median adalah 22.00. Hasil uji statistik didapatkan $p$-value sebesar $0,450>\alpha$ $=0,05$ yang artinya tidak ada perbedaan yang signifikan antara sikap kelompok perlakuan dengan kelompok kontrol setelah pelatihan (post test 1 ).

Hasil analisis nilai median skor sikap pada kelompok intervensi setelah dilakukan pelatihan (post test 2) adalah 22,00 dan untuk kelompok kontrol 21,00. Hasil uji statistik didapatkan $p$-value sebesar $0,0001<\alpha=0,05$ yang artinya ada perbedaan sangat signifikan antara sikap kelompok intervensi dengan kelompok kontrol pada post test 2 .

Hasil analisis menunjukkan terjadi peningkatan nilai median sikap sebelum intervensi pelatihan 19,00 menjadi 22,00 sesudah pelatihan pada kelompok intervensi yaitu terjadi peningkatan nilai median adalah 3,00. Hasil uji statistik menunjukkan $p$ value sebesar $0,0001<\alpha=0,05$ yang berarti ada perbedaan sangat signifikan antara sikap responden sebelum pelatihan dengan sikap responden sebulan setelah pelatihan.

Hasil analisis menunjukkan nilai median sikap kelompok kontrol sebelum adalah 20.00 dan, 1 bulan setelah pembagian leaflet meningkat menjadi 21,00. Terjadi peningkatan nilai median pengetahuan antara sebelum dan sesudah pelatihan adalah 1,00 . Hasil uji statistik menunjukkan nilai $p$-value sebesar $0,042<\alpha=0,05$ yang berarti ada perbedaan sangat signifikan antara sikap responden sebelum dan sesudah intervensi.

3. Perbedaan praktik responden antara kelompok intervensi dan kelompok kontrol

Perbandingan rerata skor praktik antara kelompok intervensi dan kelompok kontrol dilakukan untuk mengetahui perbedaan rerata skor praktik kader sebelum dilaksanakan pelatihan dan sesudah pelatihan (pre test, post test 1, post test 2). Nilai median skor praktik pada pada kelompok intervensi lebih besar yaitu 16,00 daripada praktik responden pada kelompok kontrol yaitu 11,00. Berdasarkan uji beda Mann Whitney didapatkan $p$-value sebesar 0,0001 yang artinya ada perbedaan signifikan antara praktik responden hasil post test 2 antara kelompok perlakuan dengan kelompok kontrol.

\section{Analisis pengaruh pelatihan terhadap pengetahuan, sikap dan praktik responden}

Analisis pengaruh pelatihan terhadap pengetahuan, sikap, dan praktik responden, dilakukan sebanyak dua kali, yaitu analisis pengaruh pelatihan terhadap pengetahuan, sikap dan praktik berdasarkan hasil post test 1 dan terhadap pengetahuan, sikap, dan praktik berdasarkan hasil post test 2 . 
JKT, 2018;9(1):32-44. Pengaruh Pelatihan terhadap Pengetahuan, Sikap, dan Praktik

Jacomina Anthonete Salakory

1. Pengaruh pelatihan terhadap pengetahuan responden tentang pencegahan HIV/ AIDS

Gambar 1. menunjukkan adanya peningkatan nilai median pengetahuan pengetahuan dari 14,00 (pre test) menjadi 17,00 (post test 1 ) dan 18,00 (post test 2 ) dengan $p$-value yang dihasilkan pada uji Wilcoxon jauh di bawah $\alpha=0,05(0,0001)$ artinya ada pengaruh pelatihan yang sangat signifikan terhadap pengetahuan responden.

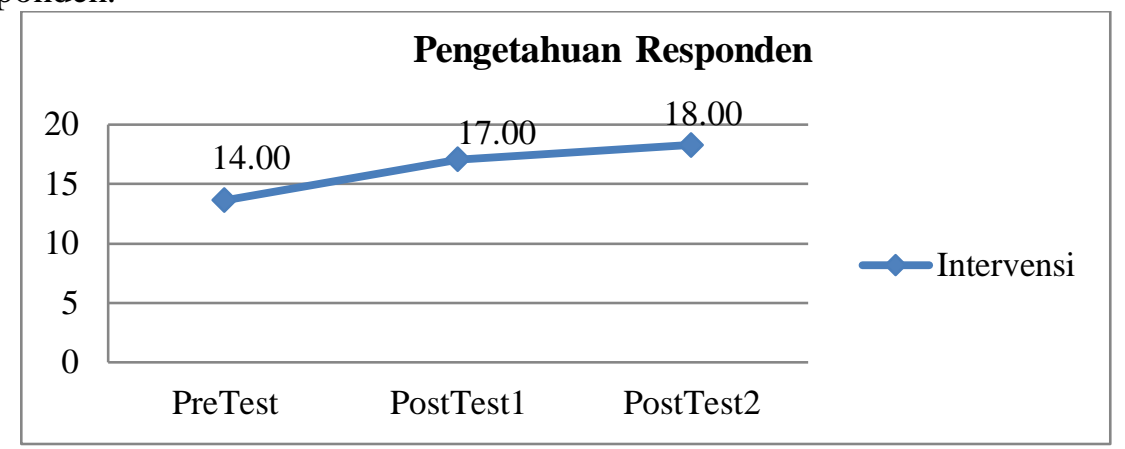

Gambar 1. Pengaruh pelatihan terhadap pengetahuan responden pada kelompok intervensi

2. Pengaruh pelatihan terhadap sikap responden terhadap penyuluhan pencegahan HIV/AIDS

Gambar 2. menunjukkan adanya peningkatan nilai median skor pengetahuan dari 19,00 (pre test) menjadi 22,00 (post test 1 ) dan 22,00 (post test 2) dengan $p$-value yang dihasilkan pada uji Wilcoxon jauh di bawah $\alpha=0,05(0,0001)$ artinya ada pengaruh pelatihan yang sangat signifikan terhadap pengetahuan responden.

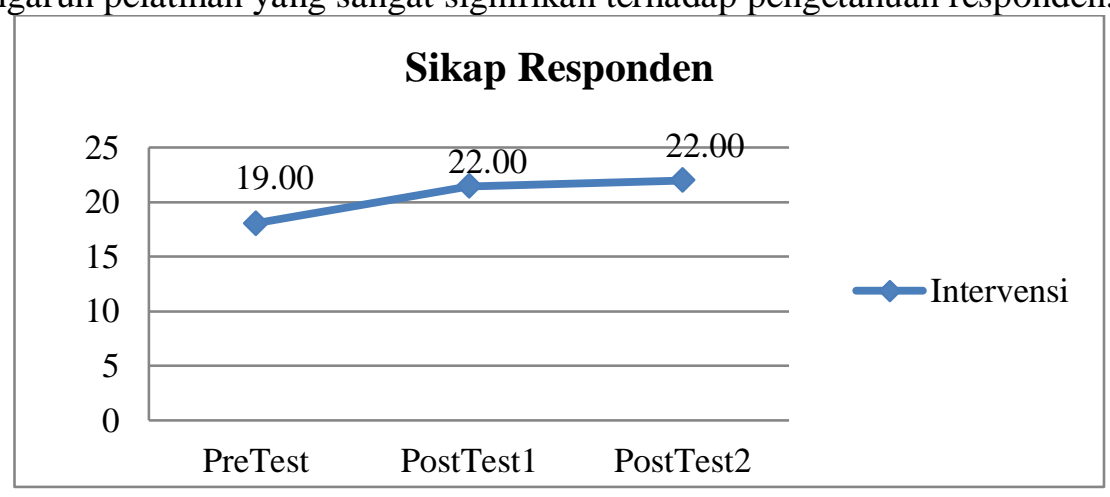

Gambar 2. Pengaruh pelatihan terhadap sikap responden pada kelompok intervensi

3. Pengaruh pelatihan terhadap praktik responden dalam penyuluhan pencegahan HIV/AIDS

Gambar 3. menunjukkan bahwa tidak ada peningkatan nilai median skor praktik responden dari pre test ke post test 1 . Berdasarkan uji Wilcoxon dihasilkan p-value $1,0<\alpha=0,05$ yang berarti tidak ada pengaruh pelatihan signifikan terhadap praktik responden pada post test 1 .

Terjadi peningkatan nilai median praktik responden dari 0,0 (post test 1 ) menjadi 16,00 (post test 2). Peningkatan skor ini menjadi bukti adanya pengaruh pelatihan terhadap praktik, semakin jelas terlihat pada $p$-value yang dihasilkan pada uji Wilcoxon jauh di bawah $\alpha=0,05(0,0001)$ yang berarti ada pengaruh pelatihan sangat signifikan terhadap praktik responden pada post test 2 . Hal ini ditunjukkan dengan terdapat 33,3\% kader memberikan penyuluhan 2 kali, 20\% kader memberikan penyuluhan sebanyak 3 kali, 13,3\% memberikan penyuluhan 4 kali, 20\% memberikan penyuluhan 5 kali, 10\% kader memberikan penyuluhan 6 kali dan 3,33 kali responden memberikan penyuluhan 8 kali. 
JKT, 2018;9(1):32-44. Pengaruh Pelatihan terhadap Pengetahuan, Sikap, dan Praktik

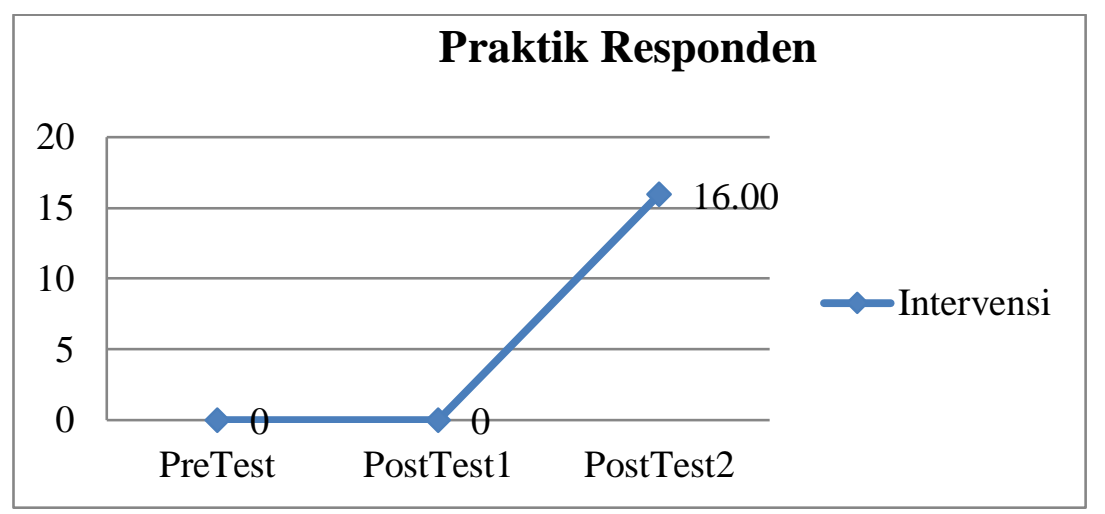

\section{Gambar 3. Grafik pengaruh pelatihan terhadap praktik kader pada kelompok inervensi}

\section{BAHASAN}

A. Pengetahuan kader antara kelompok intervensi dan kelompok kontrol tentang pencegahan HIV/AIDS

Pengetahuan awal yang telah dimiliki oleh kader diperkirakan diperoleh dari berbagai media yang ada disekitar baik media elektronik maupaun media cetak. Hal ini sejalan dengan pendapat Notoatmodjo bahwa pengetahuan seseorang sangat dipengaruhi oleh faktor pendidikan, pekerjaan, pengalaman dan informasi yang diterima oleh seseorang yang berupa pesan-pesan kesehatan melalui media cetak atau elektronik. Pengetahuan yang telah dimiliki sejak awal ini, akan mempermudah kader dalam proses belajar.

Hasil post test 1 ini menunjukkan bahwa pengetahuan sebagian besar kader pada kelompok intervensi meningkat setelah mendapatkan pelatihan. Hal ini berkaitan dengan berhasilnya ingatan jangka pendek yang tersimpan dalam ingatan jangka panjang. Pengetahuan yang diterima oleh setiap orang disimpan dalam memori. Winkel, menggambarkan tahapan proses penyimpanan materi yang telah diterima adalah sebagai berikut: menerima rangsangan dari reseptor, rangsangan yang masuk ditampung dalam sensori register dan diseleksi, sehingga membentuk suatu kebulatan perseptual, pola perseptual ini masuk ingatan jangka pendek dan tinggal selama 20 detik, kemudian hasil pengolahan ini disimpan dalam ingatan jangka panjang yang dapat dipanggil sewaktuwaktu. Pada saat diperlukan informasi dapat dipanggil dari ingatan jangka panjang dan akan masuk kembali ke ingatan jangka pendek. Dalam hal ini dikenal adanya retensi dan lupa. Kedua istilah ini tidak dapat dipisahkan. Retensi mengacu pada tingkat dimana materi yang telah diperoleh masih melekat dalam ingatan, sedangkan lupa mengacu pada porsi ingatan yang hilang. Hal-hal yang mempengaruhi penyimpanan informasi dalam ingatan jangka panjang adalah tingkat dari materi yang diberikan, metode edukasi dan perbedaan individual ${ }^{7}$.

Sesuatu yang dipelajari akan membentuk pengetahuan, seringkali pengetahuan tersebut terlupakan. Hal yang membuat seseorang cenderung lupa, tergantung pengamatan berlangsung serta waktu. Menurut Done Kolb yang dikutip Sukiarko, bahwa pengetahuan sebagai hasil dari proses belajar sangat dipengaruhi oleh waktu sejak memperoleh pemaparan, akan cenderung mengalami penurunan hingga satu bulan kedepan. Oleh karena itu diperlukan suatu model belajar yang efektif untuk menekan penurunan pengetahuan seseorang ${ }^{4}$.

B. Sikap kader tentang penyuluhan/sosialisasi pencegahan IMS, HIV/AIDS antara kelompok intervensi dan kelompok kontrol

Green L.W menyatakan sikap merupakan salah satu faktor yang mempermudah terjadinya perubahan perilaku pada seseorang. Sikap kader yang setuju berarti kader 
dengan sukarela mengerjakan tugas dan tanggungjawabnya terhadap tugas rutin kader ditambahkan dengan penyuluhan tentang pencegahan HIV.

Hasil penelitian ini sesuai dengan teori Lowrence Green yang menyatakan bahwa sikap termasuk dalam faktor yang mempermudah (predisposing factor) terjadinya perubahan perilaku dan dapat berpengaruh langsung terhadap perilaku khusus seseorang ${ }^{6}$. Jadi, jika seseorang memiliki sikap yang positif, dia cenderung untuk terjadi perubahan perilaku ke arah yang positif pula.

Pernyataan ini semakin memperkuat hasil penelitian bahwa sikap kader yang mendukung penyuluhan HIV/AIDS semakin meningkat dimulai dari pre test, post test 1 dan post test 2 . Sikap kader yang semakin meningkat inilah cenderung meningkatkan praktik kader dalam penyuluhan. Newcom, salah seorang ahli psikolog sosial, menyatakan bahwa sikap merupakan kesiapan atau kesediaan untuk bertindak, dan bukan merupakan pelaksanaan motif tertentu. Dengan kata lain, fungsi sikap belum merupakan tindakan (reaksi terbuka) atau aktivitas, akan tetapi merupakan predisposisi perilaku (tindakan) atau reaksi tertutup. Sikap merupakan kesiapan untuk bereaksi terhadap objek di lingkungan tertentu sebagai suatu penghayatan terhadap suatu objek ${ }^{8,9}$.

Banyak faktor penentu (determinan) perilaku kesehatan salah satunya adalah faktor sikap, menurut Purwanto 1998, sikap adalah pandangan atau perasaan yang disertai kecenderungan untuk bertindak sesuai sikap objek tadi. Sikap positif kecenderungan tindakan adalah mendekati, menyenangi, mengharapkan obyek tertentu. Sikap negatif terdapat kecenderungan untuk menjauhi, menghindari, membenci, tidak menyukai obyek tertentu ${ }^{10}$.

\section{Praktik penyuluhan pencegahan HIV/AIDS}

Melalui hasil observasi yang dilakukan oleh petugas kesehatan saat pelaksanaan posyandu, bahwa penyuluhan yang dilakukan oleh kader pada meja ke-4 dilksanakan dengan baik, sesuai dengan materi yang tertera dalam lembar balik atau leaflet yang ada.

Kader menggunakan leaflet serta lebar balik sebagai media penyuluhan. Media inipun mendorong seseorang untuk melakukan kegiatan penyuluhan (dalam penelitian ini, kami tidak melihat sampai pengaruh media terhadap praktik kader). Pernyataan ini didukung oleh hasil penelitian yang dilakukan oleh Nuriyah dkk, menyimpulkan bahwa yang mempengaruhi kurangnya pelaksanaan penyuluhan kesehatan adalah kemampuan dalam berkomunikasi dan keberanian, kelengkapan media penyuluhan dan kasus yang ditemui di lapangan tidak sesuai dengan materi yang didapatkan selama proses pelatihan ${ }^{11}$.

Hasil penelitian ini membuktikan bahwa pelatihan dapat meningkatkan secara bermakna nilai skor pengetahuan, skor sikap dan skor praktik penyuluhan/sosialisasi pencegahan HIV/AIDS pada kader dibandingkan pemberian informasi (ceramah) dan pembagian leaflet.

\section{SIMPULAN}

1. Nilai median pengetahuan kelompok intervensi sebelum pelatihan adalah 14,00 kelompok kontrol 15,00. Hasil uji statistik didapatkan $p$-value sebesar $0,348>\alpha=0,05$, artinya tidak ada perbedaan pengetahuan signifikan antara kedua kelompok sebelum dilakukan pelatihan.

Nilai median pengetahuan kelompok intervensi setelah pelatihan terjadi peningkatan pengetahuan pada post test 13,00 poin, dan pada post test 21,00 poin total kenaikan 3,00 poin. Kelompok kontrol tidak terjadi peningkatan pengetahuan pada post test 1 namun pada post test terjadi peningkatan 2,00 poin total kenaikan 2,00 poin.

Setelah diintervensi selisih peningkatan pengetahuan 1,00 poin. Hasil uji statistik menunjukkan nilai $p$-value $0,0001<\alpha=0,05$ yang artinya ada perbedaan pengetahuan sangat signifikan antara kedua kelompok. 
2. Nilai median sikap responden pada kelompok intervensi sebelum pelatihan adalah 19,00 pada kelompok kontrol 20,00. Hasil uji statistik didapatkan $p$-value sebesar $0,057>\alpha=$ 0,05 yang artinya tidak ada perbedaan signifikan antara kedua kelompok sebelum dilakukan pelatihan.

Nilai median sikap responden pada kelompok intervensi setelah pelatihan terjadi peningkatan pada post test 1 sikap 3,00 poin, dan pada post test 2 tetap atau tidak mengalami peningkatan, total kenaikan 3,00 poin.

Hasil uji statistik menunjukkan nilai $p$-value $0,0001<\alpha=0,05$ yang artinya ada perbedaan sikap sangat signifikan antara kedua kelompok setelah intervensi.

3. Nilai median praktik responden kedua kelompok sebelum pelatihan adalah 0,00 . Hasil uji statistik didapatkan $p$-value sebesar $1,0>\alpha=0,05$ yang artinya tidak ada perbedaan signifikan antara kedua kelompok sebelum dilakukan pelatihan.

Nilai median praktik responden pada kelompok intervensi setelah pelatihan 16,00 pada kelompok kontrol 11,00. Hasil uji statistik menunjukkan nilai $p$-value $0,0001<\alpha=0,05$ yang artinya ada perbedaan praktik sangat signifikan antara kelompok intervensi dan kelompok kontrol setelah intervensi.

4. Praktik penyuluhan responden pada kelompok intervensi setelah intervensi yang masih kurang adalah $20,0 \%$ responden pada kelompok intervensi belum memberikan penyuluhan dengan metode ceramah dan $32,7 \%$ responden tidak memberikan penyuluhan secara individu.

\section{SARAN}

1. Kepada Dinas Kesehatan Kota Ambon

a. Kader yang telah dibentuk ini dapat digunakan sebagai tenaga penyuluh dalam kegiatan penyuluhan.

b. Perlu dilakukan lagi penyegaran kader secara periodik.

2. Kepada masyarakat, mengembangkan ilmu pengetahuan yang telah disampaikan oleh kader, jangan berhenti menyampaikan tentang pencegahan HIV/AIDS.

\section{UCAPAN TERIMA KASIH}

Terlaksananya penelitian ini berkat kerjasama dari berbagai pihak, untuk itu perkenanlah kami mengucapkan terimakasih kepada:

1. Pemerintah Provinsi Maluku, Pemerintah Kota Ambon, Pemerintah Desa Galala dan Negeri Hative Kecil, Kepala Puskesmas Hative Kecil, Tawiri, yang telah mengijinkan peneliti untuk meneliti.

2. Narasumber

3. Kader.

Tuhan Yang Maha Kuasa Memberkati kita sekalian.

\section{RUJUKAN}

1. Direktorat Jenderal Pemberantasan Penyakit Menular dan Penyehatan Lingkungan Pemukiman (PPM \& PLP), Alat kelamin dan semua yang perlu kita ketahui tentang Penyakit Menular Seksual. Buku Saku Penjangkau Masyarakat, 1997.

2. Kementerian Kesehatan RI Direktorat Jenderal Pengendalian dan Penyehatan Lingkungan. Pedoman Nasional Pencegahan Penularan HIV dari Ibu ke Anak, Kementerian Kesehatan RI, Jakarta, 2011.

3. Kirk Patrick DL. EvaluationTraining Program, Barret-Publishers, Inc. San Fransisco, 1994.

4. Sukiarko, Pengaruh Pelatihan dengan Metode Belajar Berdasarkan Masalah terhadap Pengetahuan dan Ketrampilan Kader Gizi dalam Kegiatan Posyandu. Tesis. UNDIP, 2007.

5. Green LWdan Kreuter M., Health Promotion Planning and Aducation and Environmental approach. California: Mayfield Publising Co; 2000. 
JKT, 2018;9(1):32-44. Pengaruh Pelatihan terhadap Pengetahuan, Sikap, dan Praktik......

Jacomina Anthonete Salakory

6. Green LW dan Kreuter M., Health Promotion Planning and Aducation and Environmental approach. California: Mayfield Publising Co; 2000.

7. Barbados., Empowering Workers and Communities in the Response to HIV Teaching Manual Based Peer Educators, US Department of Labour, 2008.

8. Notoatmodjo, S., Promosi Kesehatan,Teori dan Aplikasi. PT. Rineka Cipta: Jakarta, 2010.

9. Azwar S. Sikap Manusia. Teori dan Aplikasinya. Liberty, Yogyakarta, Edisi ke-2, 2012

10. Purwanto, MN. Psikologi Pendidikan, PT. Remaja Rosdakarya, Bandung. 2004.

11. Nuriyah E., Rimbawan, Astika dkk, Faktor-faktor yang menentukan Efektivitas Kader di Bali, (Tesis), 2007. 